\title{
The influence of cement type and admixture on life span of reinforced concrete utility poles subjected to the high salinity environment of Northeastern Brazil, studied by corrosion potential testing
}

\section{(A influência do tipo de cimento e adição na vida útil de postes de concreto armado submetidos ao ambiente de alta salinidade do Nordeste do Brasil, estudada pela técnica de potencial de corrosão)}

\author{
A. Joukoski ${ }^{1,2}$, K. F. Portella , O. Baron ${ }^{2}$, C. M. Garcia ${ }^{2}$, G. R. Vergés ${ }^{1,2}$, A. Sales ${ }^{2}$, J. F. de Paula ${ }^{3}$ \\ ${ }^{1}$ Universidade Federal do Paraná, UFPR \\ Centro Politécnico da UFPR, Curitiba, PR, 81531-980 \\ ${ }^{2}$ Instituto de Tecnologia para o Desenvolvimento, LACTEC \\ C.P. 19067, Curitiba, PR, 81531-980 \\ ${ }^{3}$ Empresa Energética de Sergipe, ENERGIPE \\ R. Ministro Apolônio Sales 81, Aracaju, SE, 49040-230 \\ portella@lactec.org.br
}

\begin{abstract}
Reinforced concrete structures installed in coastal zones have constantly been threatened by environmental damaging elements. The chloride ion is known as one of the most aggressive of these elements, causing, among other damages, corrosion of the steel reinforcement and then degradation of the concrete matrix. The goal of this work was to determine the influence of cement type on the resistance and durability of reinforced concrete samples with $25 \mathrm{~mm}$ cover thickness, when submitted to aging in a $3.4 \%$ sodium chloride aqueous solution and in a high salinity marine environment. Reinforced concrete light poles were cast following the same batching procedures, and after the curing period, they were exposed to atmosphere in a corrosion station near Aracaju, Sergipe State, Northeastern Brazil's coast. Two concrete mixtures were made using CPII-F 32 (filler-modified Portland cement): a mix with no admixture and a mix with addition of 8\% silica fume swapping fine aggregates. Another mixture was batched with CPV-ARI RS (high-early-strength Portland cement, with sulfur resistance). All the three mixtures were designed with cement content of about $350 \mathrm{~kg} / \mathrm{m}^{3}$. The performance of the structures was evaluated from the results of physicochemical, mechanical and electrochemical testing, after over a year of natural aging. Corrosion potentials of the reinforced concrete samples and of the cast utility poles were measured in terms of the aging time at the natural environment and under chloride ion accelerated aging at laboratory. The half-cell potential measurements showed that the best results were obtained from the mixture containing CPII-F 32 cement and silica fume, followed by the concrete made with CPV-ARI RS cement. The mixture batched with CPII-F 32 cement without admixture presented the worst durability performance.
\end{abstract}

Keywords: chloride ion, corrosion of steel reinforcement, degradation of concrete, reinforced concrete light pole, electrochemical impedance spectroscopy.

\section{Resumo}

Estruturas de concreto armado instaladas em zonas costeiras têm sido constantemente ameaçadas por elementos ambientais nocivos. $O$ ion cloreto é conhecido como um dos mais agressivos destes elementos, causando, entre outros danos, corrosão da armadura de aço e posterior degradação da matriz de concreto. O objetivo deste trabalho foi determinar a influência do tipo de cimento na resistência e durabilidade de corpos-de-prova de concreto armado com $25 \mathrm{~mm}$ de cobrimento, quando submetido a envelhecimento em uma solução aquosa de 3,4\% de cloreto de sódio e pela exposição a uma atmosfera marinha de alta salinidade. Postes de concreto armado foram confeccionados seguindo a um mesmo procedimento de mistura e, após o período de cura, foram expostos à atmosfera em uma estação de corrosão situada próximo de Aracaju, estado de Sergipe, na costa nordeste do Brasil. Dois traços de concreto foram elaborados usando-se cimento CPII-F 32 (cimento Portland composto com filer): uma mistura sem qualquer adição e uma com adição de $8 \%$ de sílica ativa, em substituição aos agregados miúdos). Uma outra mistura foi preparada com cimento CPV-ARI RS (cimento Portland de alta resistência inicial, resistente a sulfatos). Todas as três misturas foram definidas para um consumo de cimento de aproximadamente $350 \mathrm{~kg} / \mathrm{m}^{3}$. O desempenho das estruturas foi avaliado a partir dos resultados de testes físico-químicos, mecânicos e eletroquímicos, após mais de um ano de envelhecimento natural. Os potenciais de corrosão dos corpos-de-prova de concreto armado e dos postes confeccionados foram medidos em função do tempo de envelhecimento no ambiente natural e sob envelhecimento acelerado por íon cloreto no laboratório. As medidas de potencial de meia-célula mostraram que os melhores resultados foram obtidos pela mistura contendo cimento CPII-F 32 e sílica ativa, seguidos pelo concreto preparado com cimento CPV-ARI RS. A mistura feita apenas com cimento CPII-F 32 apresentou o pior desempenho em termos de durabilidade.

Palavras-chave: ion cloreto, corrosão da armadura de aço, degradação do concreto, poste de concreto armado, espectroscopia de impedância eletroquímica. 


\section{INTRODUCTION}

The serious problem of service life reduction of reinforced concrete structures located at coastal zones, caused by the corrosion of its steel reinforcement and by the degradation of concrete, is already well known [1]. Special care is required for concrete components used for electric energy distribution and public illumination systems, such as light poles and crossarms [2], due to the risk of injuries or even death of pedestrians caused by failure of the deteriorated structures. At Northeastern Brazil's coast, where high salinity rates are combined with a high annual average temperature climate and high relative humidity in the night period, deterioration problems are often met. In that region, is verified that this kind of structure presents less than $25 \%$ of the recommended service life $[2,3]$.

Most cases of corrosion and degradation of reinforced concrete of coastal structures are the consequence of electrochemical reactions started by the presence of chloride ions [4]. After its contact with the poles and crossarms surfaces, the chloride ion can diffuse through the concrete cover and reach the steel reinforcement before the end of the planned service life of the structure [5]. Significant concentrations of chloride ion in the concrete can produce depassivation of steel [5].

The corrosion of the steel reinforcement in concrete, as well as the methods for its detection, is the subject of many studies all over the world, mainly using non-destructive techniques. The electrochemical impedance spectroscopy (EIS) and corrosion potential (or half-cell potential) techniques are two of the most important and useful methods for evaluating the behavior of many construction materials, as much for determining corrosion speed as for detecting the ingress of aggressive elements into the concrete until reaching the reinforcement steel $[6,7]$.

\section{EXPERIMENTAL}

\section{Materials characterization}

All materials used in the concrete mixtures were submitted to physicochemical analysis. The cements used were CPII-F 32 (filler-modified Portland cement), from two different manufacturers, and CPV-ARI RS (high-early-strength Portland cement, with sulfur resistance) types.

Both fine and coarse aggregates were from Curitiba and Aracaju cities areas, in the Southern and Northeastern Brazil, respectively, and consisted of crushed basalt stone with maximum nominal sizes of $19 \mathrm{~mm}$ (for samples and poles casting) and $9.5 \mathrm{~mm}$ (only for poles), and of washed natural medium sand.

Potential alkali reactivity testing of these aggregates and cements was done complying with ASTM C 1260-94 standard [6].

\section{Concrete sample mixtures}

Three different concrete mixtures were cast using the two cement types described above, and with similar cement contents, as shown in Table I. The slump for all mixtures was fixed at $(40 r 10) \mathrm{mm}$. Superplasticizer was used only in the silica fume concrete mixture.

\section{Specimens casting}

For each mixture, three kinds of specimens were cast:

- $100 \mathrm{~mm}$ diameter cylindrical concrete specimens: 200 $\mathrm{mm}$ of height, for determination of compressive strength at 3 , 14 and 28 days after casting, and after 1, 3 and 7 months of aging by immersion in a $3.4 \%$ sodium chloride $(\mathrm{NaCl})$ aqueous solution;

Table I - Mixture proportions and some properties of fresh concrete.

[Tabela I - Proporções das misturas e algumas propriedades do concreto fresco.]

\begin{tabular}{lccc}
\hline Mixture/sample & CF347 & SF350 & RS344 \\
\hline Cement type & CPII-F 32 & CPII-F 32 & CPV-ARI RS \\
\hline Admixture & - & $8 \%$ silica fume & - \\
\hline Quantities $\left(\mathbf{k g} / \mathbf{m}^{\mathbf{3}}\right)$ & & & \\
\hline cement & 347 & 350 & 344 \\
\hline silica fume & - & 28 & - \\
\hline fine aggregate & 656 & 643 & 654 \\
\hline coarse aggregate $(19$ mm) & 1218 & 1157 & 1211 \\
\hline water & 200 & 174 & 186 \\
\hline superplasticizer & - & 5.25 & - \\
\hline Water/cementitious materials ratio & 0.58 & 0.46 & 0.54 \\
\hline Slump $(\mathbf{m m})$ & 50 & 50 & 35 \\
\hline Unit weight $\left(\mathbf{k g} / \mathbf{m}^{\mathbf{3}}\right)$ & 2421 & 2357 & 2395 \\
\hline Air content $\mathbf{( \% )}$ & 0.0 & N.E. & 0.8 \\
\hline
\end{tabular}

N.E.: not evaluated 
- $150 \mathrm{~mm}$ diameter cylindrical concrete specimens: 300 $\mathrm{mm}$ high, for permeability testing and determination of specific density, absorption and porosity of concrete (after 28 days from casting); and

- prismatic reinforced concrete specimens: $71 \mathrm{~mm}$ large, $100 \mathrm{~mm}$ high and $44 \mathrm{~mm}$ thick. The concrete cover thickness (25 mm) was selected due to the usual thickness of Brazilian light poles. The reinforcement of the prismatic specimens consisted of three bars of class CA-50 steel (carbon-steel, with $500 \mathrm{MPa}$ of tensile strength), $6.3 \mathrm{~mm}$ in diameter and $125 \mathrm{~mm}$ long. Both extremities of each bar were protected by a tarbased, corrosion-protective coating, resulting in only a central steel-exposed region of the bar with about $35 \mathrm{~mm}$ of length. In Fig. 1 are shown more details about the prismatic specimen.

After casting, all specimens were left covered in the casting room for 24 hours, then demolded and placed in a moist curing room, at $\left(23\right.$ r 2) ${ }^{\circ} \mathrm{C}$ and $95 \%$ minimum relative humidity, for 28 days.
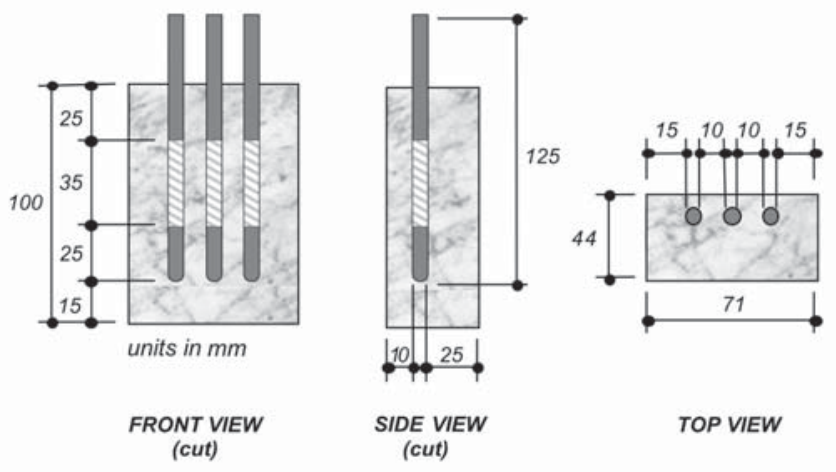

Figure 1: Prismatic specimen sketch.

[Figura 1: Esquema do corpo-de-prova prismático.]

\section{Reinforced concrete light poles}

Five light poles were produced at a selected manufacturer of pre-cast reinforced concrete products, located in Aracaju, Sergipe State, Northeastern Brazil. They were double-tee crosssection shaped, B type, $11 \mathrm{~m}$ long, and with 300 daN of nominal strength, complying with Brazilian standard NBR 8451-98 [2]. From these, three posts with different compositions were investigated. The first light pole (coded as P222) was cast with CPII-F 32 cement and $8 \%$ silica fume admixture in substitution of fine aggregate. The second pole (named P225) was cast with CPV-ARI RS cement, and the third one (P232), which was elected as a reference product, was cast by the manufacturer with approximately $350 \mathrm{~kg} / \mathrm{m}^{3}$ of CPII-F 32 cement. Pole P232 was randomically picked out from a product stack at the industrial plant, observing the selection of a sample with similar casting date.

All concrete poles were cast with no change of the industrial process, in order to investigate only the influence of the materials and mixtures on the service life of the products. The mixture proportions of the utility poles can be seen in Table II. Data from the manufacturer standard pole were not available, excepting the cement type and approximate cement content.

\section{Marine corrosion station}

A marine environment corrosion site, shown in Fig. 2, was built at Caueira Beach, in Itaporanga D'Ajuda, a district near Aracaju. The corrosion station is located approximately at the coordinates $37^{\circ} 40^{\prime} \mathrm{W}$ and $10^{\circ} 09^{\prime} \mathrm{S}$, and about $2 \mathrm{~m}$ above the high tide line of the Atlantic Ocean. In this place, average annual temperature is $26.7^{\circ} \mathrm{C}$ and annual pluviometry is of about $1400 \mathrm{~mm}$.

The prismatic reinforced concrete samples and the

Table II - Mixture proportions of the concrete poles.

[Tabela II - Proporções de mistura dos postes de concreto.]

\begin{tabular}{lccc}
\hline Mixture/product & P232 & P222 & P225 \\
\hline Cement type & CPII-F 32 & CPII-F 32 & CPV-ARI RS \\
\hline Admixture & - & $8 \%$ silica fume & - \\
\hline Quantities $\left(\mathbf{k g} / \mathbf{m}^{3}\right)$ & & & \\
\hline cement & About 350 & 350.0 & 350.0 \\
\hline silica fume & - & 28.0 & - \\
\hline fine aggregate & N.A. & 642.7 & 681.8 \\
\hline coarse aggregate $9.5 \mathrm{~mm}$ & N.A. & 520.7 & 500.6 \\
\hline coarse aggregate $19.0 \mathrm{~mm}$ & N.A. & 636.3 & 611.8 \\
\hline water & N.A. & 173.9 & 185.5 \\
\hline superplasticizer & - & 5.25 & - \\
\hline Water/cementitious materials ratio & N.A & 0.46 & 0.54 \\
\hline
\end{tabular}

N.A.: not available 


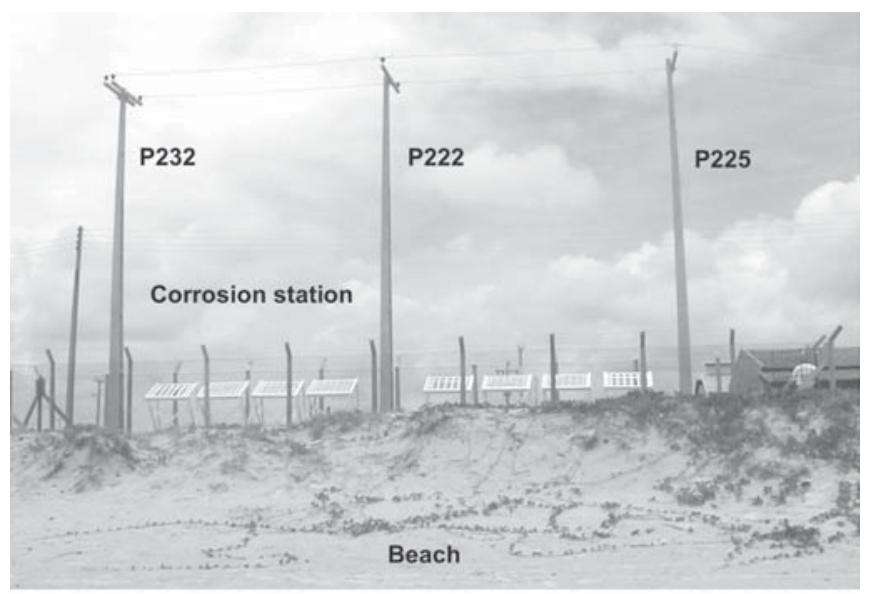

Figure 2: View of the corrosion station at Caueira Beach (Itaporanga d'Ajuda district), Sergipe State, Northeastern Brazil.

[Figura 2: Vista da estação de corrosão na Praia da Caueira (município de Itaporanga d'Ajuda), estado de Sergipe, nordeste do Brazil.]

produced light poles were exposed to the costal environment for over one year. Measurement of chloride deposition rate, by wet candle method, was done within this period.

Electrochemical impedance spectroscopy (EIS) and corrosion potential

After 28 days of curing, the aging process of prismatic specimens by the $\mathrm{NaCl}$ solution started, as well as the EIS testing, which results to be presented [8]. Aging cells, consisting of two PVC piping caps, were fastened to each specimen, as shown in Fig. 3.

The container at the side of the $25 \mathrm{~mm}$ concrete cover was filled with the saline solution, whereas the other was filled with distilled water. This configuration was designed in order to simulate the regular conditions which actual light poles

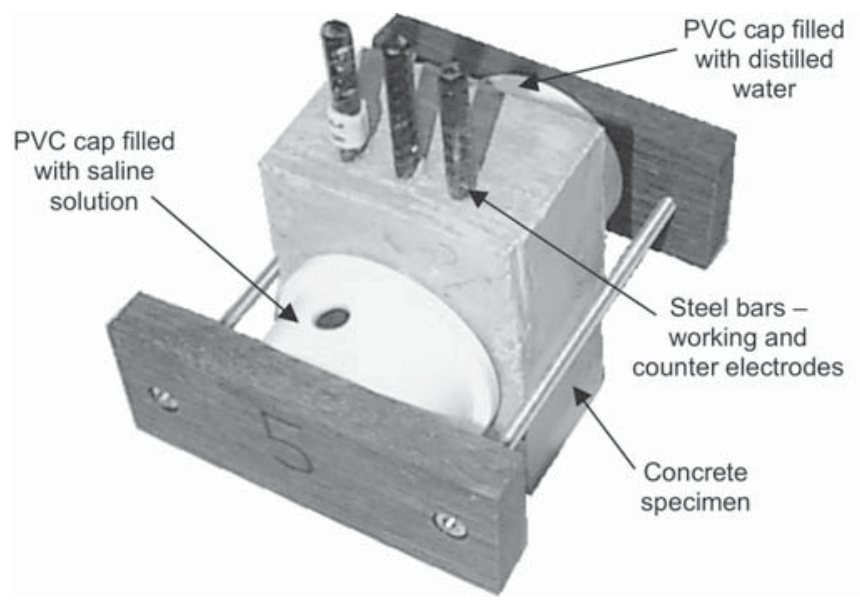

Figure 3: Aging cell photograph.

[Figura 3: Fotografia da célula de envelhecimento.] installed along the coast are subjected to, i.e., the salt-water splashing on one side, and the rain water washing on the other. These different $\mathrm{NaCl}$ concentrations also induced chloride ion migration through the concrete thickness of the samples.

The steel bars of the specimen played as the working and the auxiliary electrodes. A saturated calomel reference electrode was also used. The main equipment employed was an EcoChemie potentiostat/galvanostat, Autolab 20 model. Impedance measurements followed 66 decreasing frequencies within $50 \mathrm{kHz}$ and $10 \mathrm{mHz}$, and with amplitude signal of $5 \mathrm{mV}$. This test was developed only in the lab concrete samples. Field specimens and light poles subjected to natural aging were submitted to rest potential testing, by using a digital multimeter and the same saturated calomel reference electrode. The metallic rebar of the poles was connected to the multimeter as the working electrode. An average potential of thirty measurements was obtained from the testing at the both sides of the bottom region of poles (butt), just above the embedment line.

The corrosion potential measurements and the impedance tests were performed according to the recommendations of ASTM C 876-91 (9), for over a year of aging. This standard test method also indicates the relative probability of corrosion activity in terms of the half-cell potential reading, for a $\mathrm{CulCuSO}_{4}$ reference electrode. In order to evaluate corrosion probability using the saturated calomel reference electrode, the values provided by ASTM C 876-91 had to be converted. For this electrode, a potential less negative than $-275 \mathrm{mV}$ indicates a $90 \%$ probability of no corrosion; for a reading more negative than $-425 \mathrm{mV}$, there is a $90 \%$ probability of corrosion; and for values between $-275 \mathrm{mV}$ and $-425 \mathrm{mV}$, corrosion activity is uncertain.

\section{Compressive strength}

The $100 \mathrm{~mm}$ diameter cylindrical concrete specimens were tested for compressive strength at 3,14 and 28 days of curing. Additional specimens were immersed for aging in the saline solution and tested after about 1,3, and 7 months of immersion.

\section{Potential alkali reactivity of cement and aggregate}

Mortar-bars, with aggregates from Curitiba and Aracaju cities and CPII-F 32 cement (coded as CP222PR and CP222SE, respectively), and mortar-bars with aggregates from Aracaju and CPV-ARI RS cement (CP225SE), were cast and tested according to the ASTM C 1260-94 specification [10]. Other mortar-bars, produced with CPII-F 32 cement and $8 \%$ silica fume in substitution of fine aggregate (natural sand) from Aracaju (code CP222SF), were tested. From ASTM C 126094, the expansion results may be evaluated as follow:

- expansions less than $0.10 \%$ at 16 days after casting are indicative of innocuous behavior in most cases;

- expansions of more than $0.20 \%$ at 16 days after casting are indicative of potentially deleterious expansion; and

- expansions between $0.10 \%$ and $0.20 \%$ at 16 days after casting include both aggregates that are known to be innocuous and deleterious in field performance. In this specific case it is 
important to conduct the test until 28 days and compare the expansion final results; if it results higher than $0.20 \%$, consider indicative of potentially deleterious.

\section{RESULTS AND DISCUSSION}

The chemical compositions of the two CPII-F 32 cements (from Aracaju and Curitiba) and of CPV-ARI RS cement were in accordance with the cement standardizations limits, excepting the equivalent $\mathrm{Na}_{2} \mathrm{O}$, which results $(0.78 \%, 0.82 \%$ and $0.78 \%$, respectively) were higher than the limit $(0.6 \%)$ recommended by Taylor in order to minimize alkali-aggregate reactions [11]. As discussed in the literature, these concentrations may promote expansive reactions if the aggregates are potentially reactive $[1,4,11-12]$. Joined to this is the fact that the samples are in constant contact with sodium ion from marine atmospheres or saline solutions. Experiments made by Berube and Frenete apud Shaian [13] showed that the exposure of concrete prisms produced with potentially reactive aggregates to an $1 \mathrm{M} \mathrm{NaCl}$ solution resulted in much more expansion than to an $1 \mathrm{M} \mathrm{NaOH}$ solution, at $38^{\circ} \mathrm{C}$.

Compressive strengths of mortar specimens were in agreement with the corresponding Brazilian technical specification [14].

The petrographic analysis of the aggregates from Aracaju, showed: 50 to $55 \%$ of sericite; 10 to $15 \%$ of K-feldspar, altered by sericite; 25 to $30 \%$ of quartz; followed by minor other constituents. Optical microscopy revealed strained quartz with boundary reactions. Microscopic analysis of the coarse aggregates from Curitiba presented: 50 to $55 \%$ of plagioclase; 30 to $35 \%$ of augite, 5 to $15 \%$ of olivine; and 5 to $15 \%$ of magnetite.

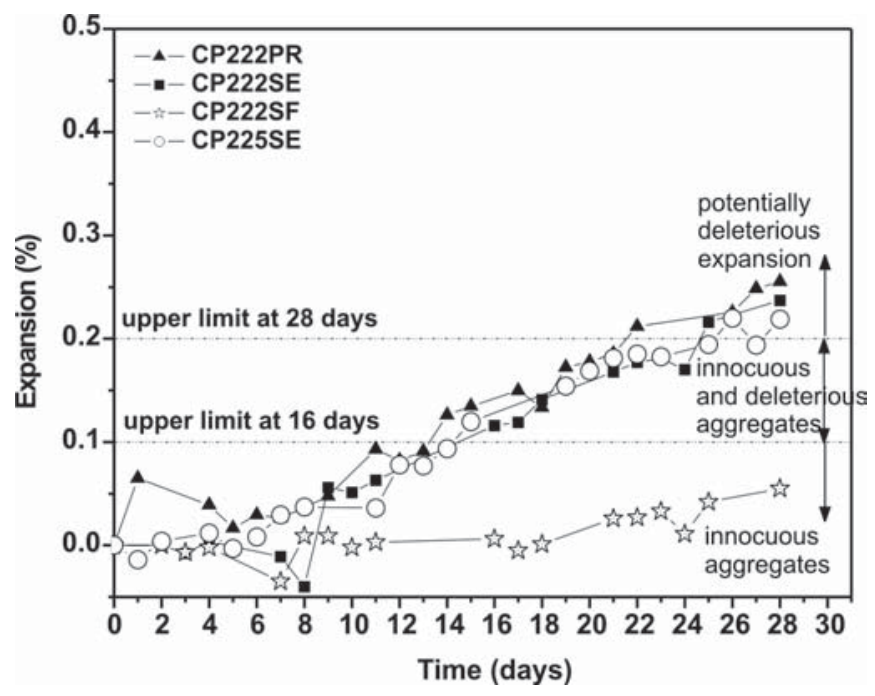

Figure 4: Potential alkali reactivity of CP222PR, CP222SE, CP222SF and CP225SE mortar-bars.

[Figura 4: Reatividade potencial álcali-agregado das barras de argamassa CP222PR, CP222SE, CP222SF e CP225SE.]
The alkali concentration of both cement types, the chemical phases and the microstructure of coarse aggregates could be responsible for the potentially deleterious expansion presented by the mortar samples. In Fig. 4 the curves of expansion are plotted against aging time of samples CP222PR, CP222SE, CP222SF, and CP225SE. All mortar-bars showed expansions beyond the recommended limits at 16 days specified by ASTM C 1260-94 standardization [10]. To confirm these results the tests were carried out until 30 days, and all samples expanded more than the recommended limits, as shown in the plot of Fig. 4.

The sample containing silica fume admixture (CP222SF) presented the best result, as shown in the same Fig. 4. This admixture reduced to a minimum the expansive reaction verified in the other concrete mixtures. These data were decisive in selecting the mix design of the cast P222 light pole, tested at Caueira Beach corrosion station (Fig. 2).

Salinity data obtained at the Caueira Beach corrosion station, from March 2002 to March 2003, are shown in Fig. 5.

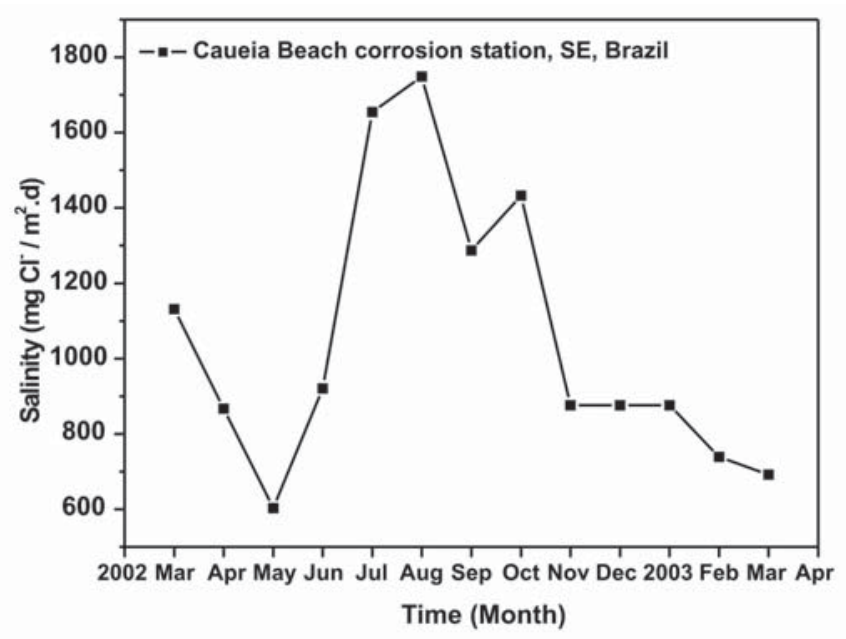

Figure 5: Atmospheric salinity, measured at Caueira Beach, from March 2002 to March 2003.

[Figura 5: Salinidade atmosférica, medida na Praia da Caueira, de março de 2002 a março de 2003.]

The mean chloride value presented of $(1087 \pm 394) \mathrm{mg} / \mathrm{m}^{2}$.day is higher than the maximum results obtained by Pintos et al [15] in ten Brazilian corrosion sites, which were about 360 $\mathrm{mg} / \mathrm{m}^{2}$.day. In the paper, the chloride deposition rate was obtained from Fortaleza, Ceará State, also in Northeastern Brazil's coastal zone. Silva, Portella, Dalledone and D'Alkaine [16] presented the results of chloride deposition rate measured in a corrosion station located at Pontal do Sul Beach, Paraná State, in the South of Brazil, during two years, from January 1987 to January 1989. The salinity rate varies from, approximately, $20 \mathrm{mg} / \mathrm{m}^{2}$.day in the winter to $120 \mathrm{mg} / \mathrm{m}^{2}$.day in the summer. These maximum values are about a tenth of the results obtained in the Caueira Beach corrosion station. Due to these results, location is classified as marine environment [17]. Based on the studies of Pintos [15] and Morcillo [17] about atmospheric corrosion of steel, a corrosion rate three 
times higher than the value presented by the first author (considering only the chloride concentration) can be expected for Caueira Beach results. Visual inspection of utility poles evaluated by Portella and Garcia [18] in Paraná's coast showed an estimated corrosion rate four times smaller than the Northeastern one.

Another particularity observed at surroundings of Caueira Beach is the intensity of the corrosive attack in the steel reinforcement and in the concrete cover of light poles. The pole surface at back seaside presented more serious damages than the side facing the seashore, which is probably due to the predominance of sea-to-coast (southeastern) wind. The prevailing wind keeps the sea-facing concrete dry, while the other face is subjected to longer periods of wetness and salinity. Allied to this is the local average daily temperature of up to $25^{\circ} \mathrm{C}$ (in 2002). This fact can be observed in Fig. 6, which shows a damaged six-year utility pole.

The environmental conditions described, joined to several manufacture problems, decrease the life span of concrete light poles and crossarms to less than 10 years, instead of 35 years recommended by the Brazilian standardization [2].

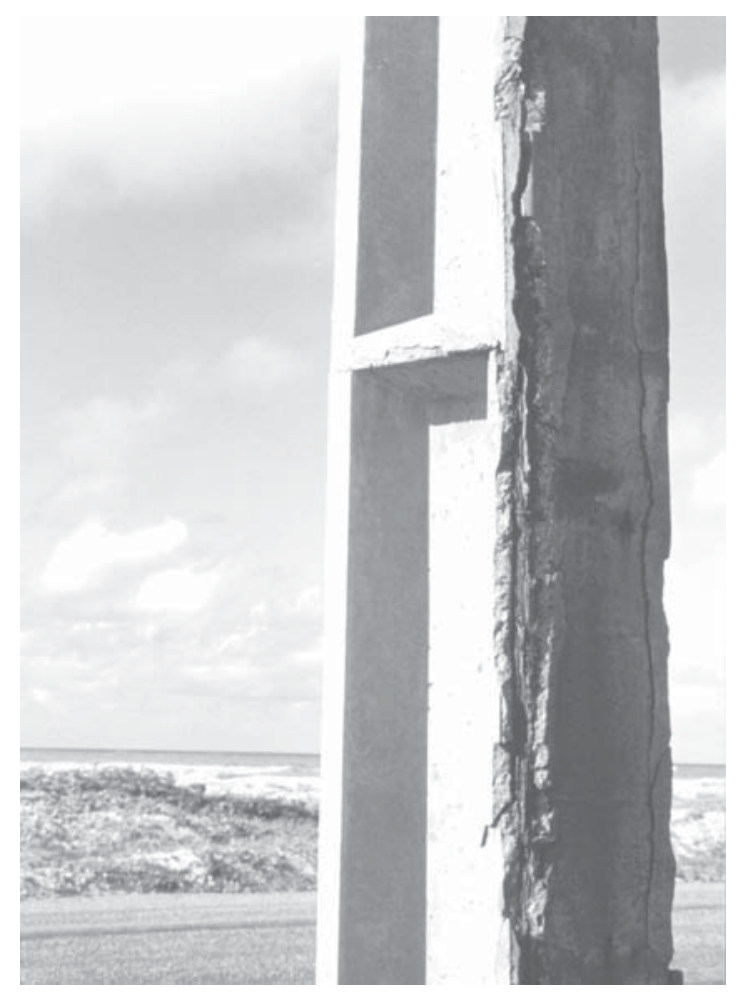

Figure 6: Concrete utility pole presenting chloride corrosion attack, at Aracaju.

[Figura 6: Poste de concreto apresentando ataque corrosivo por cloreto, em Aracaju.]

\section{Electrical properties}

The plots presented in Fig. 7 show the corrosion potentials versus time of three reinforced concrete samples subjected to aging by a $3.4 \% \mathrm{NaCl}$ aqueous solution at laboratory environment.

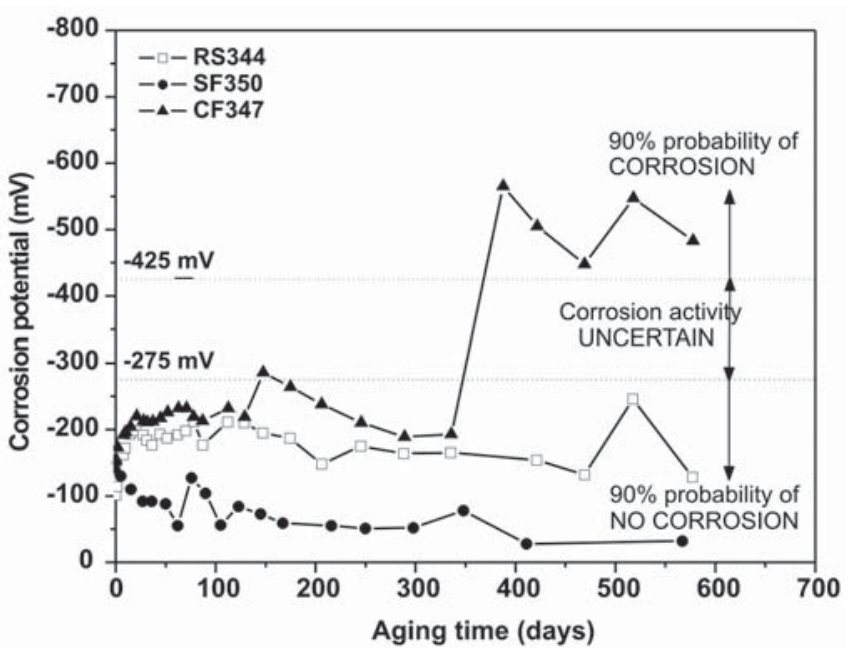

Figure 7: Corrosion potential versus laboratory aging time of RS344, SF350 and CF347 concrete samples.

[Figura 7: Potencial de corrosão versus tempo de envelhecimento em laboratório das amostras de concreto RS344, SF350 e CF347.]

The influence of cement type in RS344 sample and of silica fume admixture in SF350 was easily observed. As noted in the plots, the reinforcement steel bars didn't present substantial changing in the electric potential, within the testing period, by the imposed chloride aging. For these two samples, the potential values remained in the region where there is $90 \%$ probability of no corrosion, that is below the minimum corrosion potential line $(-275 \mathrm{mV})$.

The benefits of silica fume admixture to the SF350 sample could be denoted by a lower permeability of concrete matrix, mainly due to the cement paste compactness, as described in the literature [12]. The good performance of RS344 sample, made with CPV-ARI RS cement, could be attributed to its higher compactness too.

In Fig. 8 are shown the two fracture surfaces of SF350 and RS344 samples, respectively, viewed by scanning electron microscopy (SEM). Cracks are visible on the surface of sample made with high-early-strength cement, but no particular micrographic image was detected. Microanalysis by X-ray energy dispersive system (EDS) revealed low level chloride concentration in all parts of the assayed samples, as well as CSH elemental chemical compounds. In opposite to the results presented by Glass and Buenfeld [19], the good performance of RS344 sample in corrosion potential testing may be attributed to the concrete compactness, since the authors concluded that sulfur resistant Portland cement (SRPC) has a low level binding of chloride.

The CF347 sample presented the highest corrosion potential for steel rebar, which values attained the zone of $90 \%$ probability of corrosion, i.e., above the high corrosion potential line $(-425 \mathrm{mV})$, after about one year of aging. SEM images and EDS analysis revealed high chloride concentration in most fracture surface, as well as the presence of alkali gel and crystals into cracks and pores, as shown in Fig. 9. 

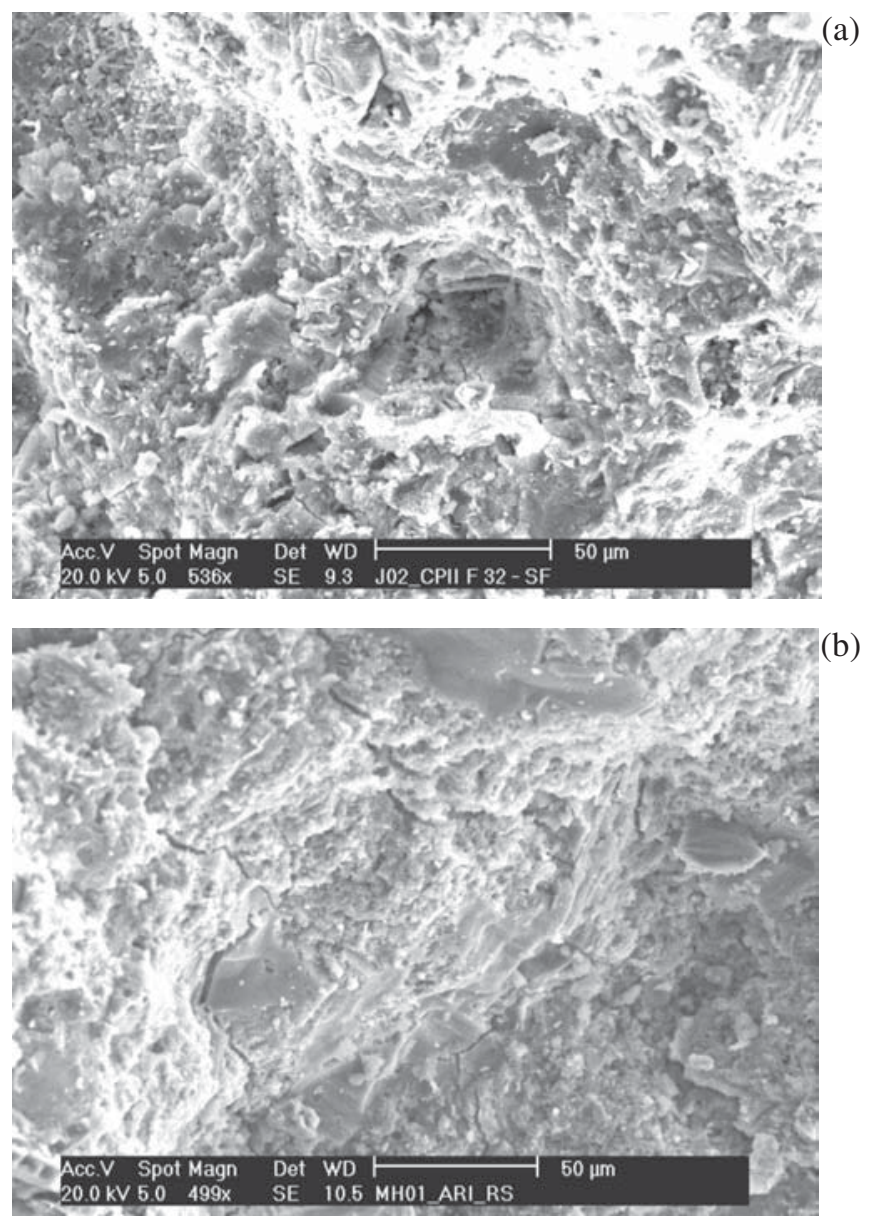

Figure 8: Scanning electron microscope images from fracture surfaces of RS344 and SF350 concrete samples.

[Figura 8: Imagens obtidas por microscópio eletrônico de varredura das superfícies de fratura das amostras de concreto RS344 e SF350.]

All tested samples were cast with concrete proportioning and cover thickness similar to the produced light poles.

The corrosion potential results of the utility poles made with these same mixtures and submitted to natural aging at Caueira Beach corrosion station are presented in Fig. 10.

The corrosion potential results of all light poles remained within the zone of $90 \%$ probability of no corrosion, during the testing period. However, the corrosion potential results of the reference utility pole (P232), seems to present the same tendency of CF347 sample - with supposed similar mixture proportion, cement type, cement content and water/ cement ratio - that is passing to the zone of uncertain corrosion activity. A photograph of the surface of this reference pole is presented in Fig. 11, where it can be seen a color alteration of concrete, iron smudges and superficial cracks along the longitudinal steel reinforcement surroundings. Apparent corrosion of a transversal reinforcing bar can also be seen.

The two other utility poles presented no visual evidence of rebar corrosion or degradation of concrete, within the analyzed period.

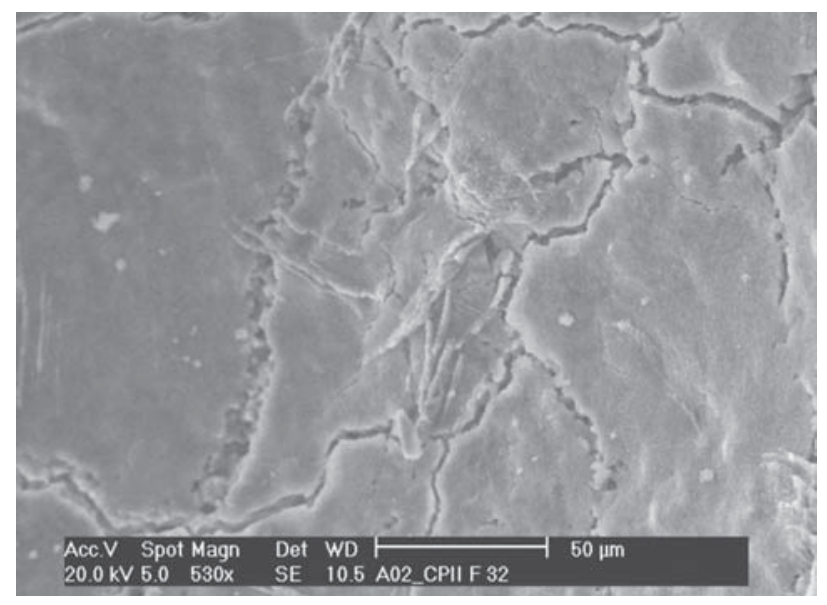

(a)

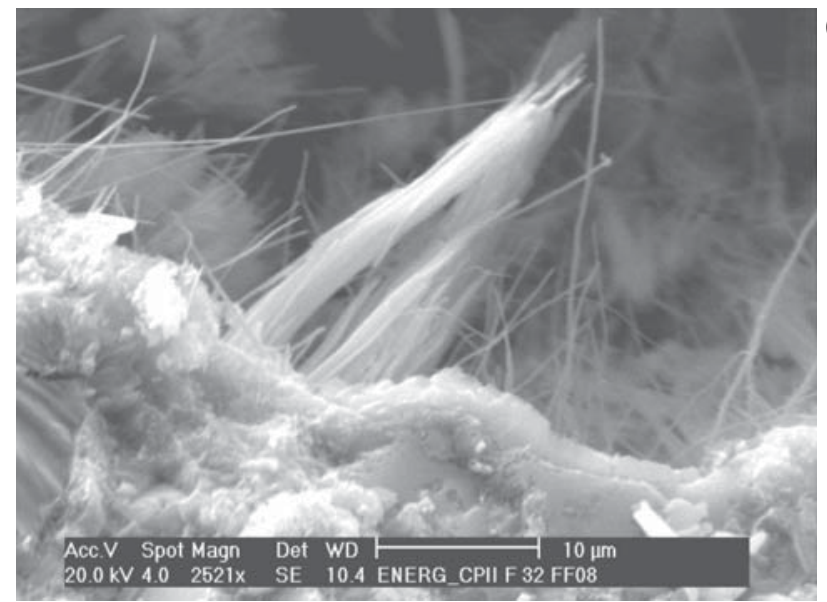

(b)

Figure 9: Scanning electron microscope images from fracture surfaces of CF347 concrete sample.

[Figura 9: Imagens obtidas por microscópio eletrônico de varredura da superfície de fratura da amostra de concreto CF347.]

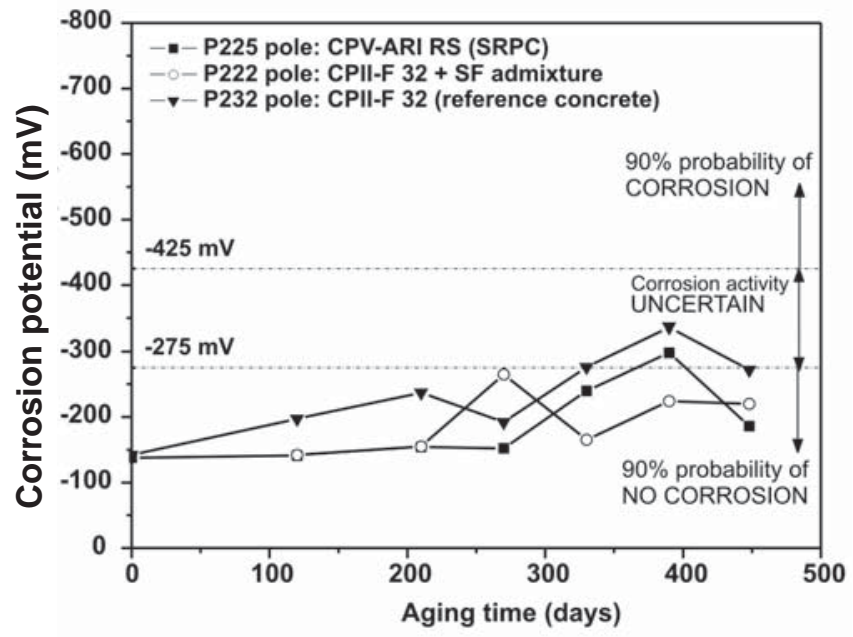

Figure 10: Corrosion potential of the lights poles submitted to the natural aging for 18 months in Caueira Beach corrosion station. [Figura 10: Potencial de corrosão dos postes submetidos a envelhecimento natural por 18 meses na estação de corrosão da Praia da Caueira.] 


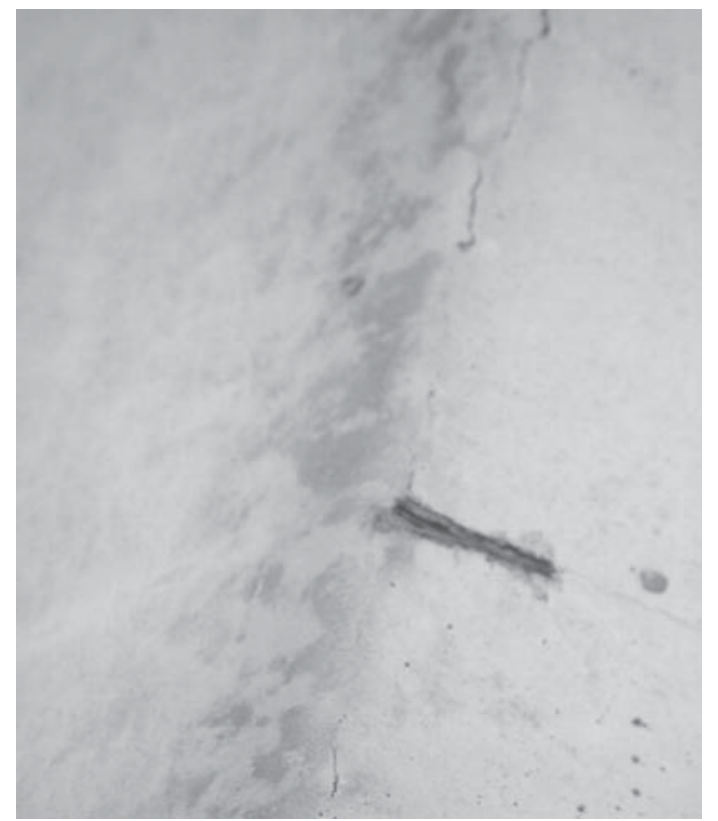

Figure 11: P232 utility pole presenting color alteration on the concrete surface, at rebar direction (iron smudges), superficial cracks and corrosion of steel reinforcement.

[Figura 11: Poste P232 apresentando alteração de cor na superfície do concreto, na direção das barras (manchamento avermelhado), trincas superficiais e corrosão das armaduras de aço.]

\section{Compressive strength results}

The mixtures containing silica fume and CPV-ARI RS cement presented higher compressive strengths than the mix made with CPII-F 32 cement and no admixture. Within the period of immersion in a $3.4 \% \mathrm{NaCl}$ solution, a tendency of decreasing strengths was noticed for all three mixtures, as shown in Fig. 12.

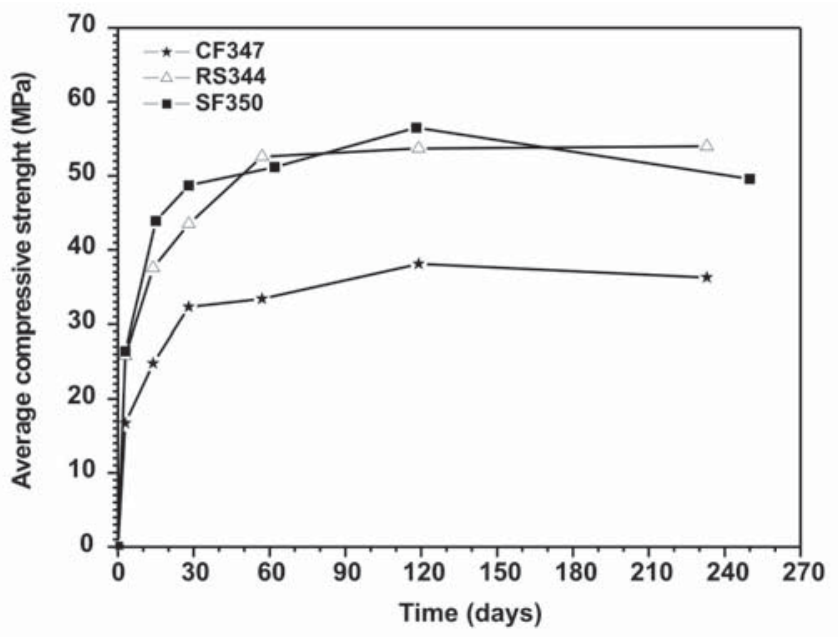

Figure 12: Compressive strength of cylindrical concrete specimens.

[Figura 12: Resistência à compressão de corpos-de-prova cilíndricos de concreto.]

\section{CONCLUSIONS}

Corrosion potentials of reinforced concrete samples cast with filler-modified Portland cement (CPII-F 32), CPII-F 32 cement plus $8 \%$ silica fume, and high-early-strength Portland cement with sulfur resistance (CPV-ARI RS), as well as of three light poles produced with similar concrete mixtures, were measured in terms of the time of exposure to actual marine environment and by chloride ion accelerated aging (using a $3.4 \% \mathrm{NaCl}$ solution) at laboratory environment.

The measurements showed that the best results were obtained from concretes made with CPII-F 32 cement and silica fume admixture, and CPV-ARI RS cement, followed by the concrete with CPII-F 32 cement and no admixture, which presented the worst results regarding durability matter.

The salinity results obtained at Caueira Beach corrosion station showed that Northeastern Brazil's coast is a very high aggressive environment, denoted by its high chloride concentration. Field inspections of several utility poles in both places indicated that corrosion in Northeastern coastal zone, which is in the range of previous studies [15, 17], is four times more aggressive than in Southern region.

The results of salinity measurements obtained in Caueira Beach may contribute to the Ibero-American corrosion map, and indicate extremely high values if compared with other data from the literature.

\section{ACKNOWLEDGEMENTS}

This work was sponsored by Companhia Energética de Sergipe (ENERGIPE), Instituto de Tecnologia para o Desenvolvimento (LACTEC), Agência Nacional de Energia Elétrica (ANEEL), and Conselho Nacional de Desenvolvimento Científico e Tecnológico (CNPq). The authors wish to thank the Engineering Post-Graduate Interdisciplinary Program at Universidade Federal do Paraná (UFPR).

\section{REFERENCES}

[1] A. M. Neville, "Propriedades do Concreto", 2a . ed., Editora PINI Ltda., S. Paulo (1997).

[2] ABNT, "Postes de Concreto Armado para Redes de Distribuição de Energia Elétrica - Especificação", NBR 8451, Rio de Janeiro (1998).

[3] K. F. Portella, C. M. Garcia, A. Joukoski, V. A. L. Azevedo, "Avaliação da Degradação, Corrosão e Sistemas de Impermeabilização de Estruturas de Concreto Armado", LACTEC/ ENERGIPE/ANEEL, Relatório técnico 1815, Aracaju, Brazil (2001) p.110.

[4] P. K. Mehta, "Concreto: Estrutura, Propriedades e Materiais", Editora PINI Ltda., S. Paulo (1995).

[5] O. Cascudo, Controle da Corrosão de Armaduras de Concreto, $1^{a}$. Ed., Editora PINI Ltda., S. Paulo; Editora da UFG, Goiânia (1997).

[6] M. Shi, Z. Chen, J. Sun, Cem. Concr. Res. 29 (1999) 1111.

[7] I. Arteaga, M. A. Talavera, J. Genesca, "Electrochemical 
Behavior of Steel in $\mathrm{Ca}(\mathrm{OH})_{2}$ Solution", in Proceedings $15^{\text {th }}$ International Corrosion Congress, Granada (2002) 293.

[8] K. F. Portella, A. Joukoski, C. M. Garcia, J. F. Paula (to be published).

[9] ASTM, "Standard Test Method for Half-Cell Potentials of Uncoated Reinforcing Steel in Concrete", C 876-91, West Conshohocken (1999).

[10] ASTM, "Standard Test Method for Potential Alkali Reactivity of Aggregates (Mortar-Bar Method)", C 1260-94, West Conshohocken (1994).

[11] H. F. W. Taylor, "Cement chemistry", Academic Press, New York (1990).

[12] K. L. Scrivener, J. F. Young, eds., "Mechanisms of Chemical Degradation of Cement-based Systems", $1^{\text {st }}$ ed., E \& FN Spon, London (1997) 455.

[13] A. Shayan, Cem. Concr. Res. 28 (1998) 25-31.

[14] ABNT, "Cimento Portland Composto", NBR 11578, Rio de Janeiro (1991).

[15] S. Pintos, N. V. Queipo, O. T. Rincón, A. Rincón, M. Morcillo, Corr. Sci. 42 (2002) 35-52.

[16] J. M. Silva, K. F. Portella, E. Dalledone, C. V. D’Alkaine, "Exposição de Materiais Metálicos em Estações Atmosféricas no Paraná, Parte I, Dois Anos de Experiência", in Anais 3o Congresso Ibero-Americano de Corrosão e Proteção, v. I, Rio de Janeiro (1989) 471.

[17] M. Morcillo, B. Chico, L. Mariaca, E. Otero, Corr. Sci. 42 (2000) 91-104.

[18] K. F. Portella, "Controle da Degradação de Estruturas de Concreto Utilizadas no Setor Elétrico", PDTI/COPEL (1998); FINEP (2000).

[19] G. K. Glass, N. R. Buenfeld, Corr. Sci. 39, 5 (1997) 10011013 .

[20] ABNT, "Cimentos Portland Resistentes a Sulfatos", NBR 5737, Rio de Janeiro (1992).

(Rec. 20/06/03, Ac. 31/10/03) 